\title{
The Limpopo textbook litigation: a case study into the possibilities of a transformative constitutionalism
}

\author{
Faranaaz Veriava \\ Senior Legal Researcher and Advocate, Section 27; LLD candidate, Faculty of Law, University of Pretoria \\ fveriava@polity.org.za
}

\begin{abstract}
In December 2015, the Supreme Court of Appeal ('SCA') in its judgment in the case of Minister of Basic Education $v$ Basic Education for All held that every learner is entitled to a textbook in every subject at the commencement of the academic year. This article discusses and analyses the judgment. In particular, it examines the contribution of the judgment to the doctrine of transformative constitutionalism as evidenced by the SCA's approach to the interpretation of the rights to basic education and equality, respectively. It discusses the reaffirmation of the principle of the duty to budget in South Africa's evolving socio-economic rights jurisprudence and finally it discusses the choice of remedy in the judgment.
\end{abstract}

Keywords: Education; schools; socio-economic rights

\section{Introduction}

On 2 December 2015, the Supreme Court of Appeal ('SCA') in its judgment in the case of Minister of Basic Education v Basic Education for All ('BEFA') ${ }^{1}$ held that every learner is entitled to a textbook in every subject at the commencement of the academic year. The judgment further explicitly noted that the corollary to this entitlement is the duty of the government to provide these textbooks to each and every learner. This $B E F A$ judgment is the culmination of litigation that was first initiated by the public interest organisation, Section 27 in 2012, in a matter that became widely referred to as the 'Limpopo textbook saga'.'

This article examines the contribution of the BEFA judgment to the doctrine of transformative constitutionalism and to South Africa's evolving socio-economic rights jurisprudence, including in respect of the normative development of the unqualified right to basic education in section 29(1) (a) of the Constitution.

\footnotetext{
1 [2016] 1 All SA 369 (SCA).

2 In 2012, The non-delivery of textbooks in the Limpopo Province became infamously referred to within the public discourse as the 'Limpopo textbook saga' because of the manner in which the National Department of Basic Education (DBE) mismanaged textbook delivery to schools in the province in 2012. See, for example L Chisholm Corruption in Education: The Textbook Saga (2012).
} 
Section II discusses the history of the Limpopo textbook case, which eventually culminated in the BEFA judgment in the SCA. In discussing the history of the case, the article refers to the three judgments in the lower courts in the following manner, the judgment of Kollapen J that was delivered in May 2012 in the case of Section $27 v$ Minister of Education is referred to as 'Textbooks 1', 'the judgment that was delivered by Kollapen J on 4 October 2012 is referred to as 'Textbooks 2', and the judgment that was delivered by Tuchten J on 5 May 2014 in Basic Education For All \& Others $v$ Minister of Basic Education is referred to as 'Textbooks 3'.

Section III analyses the BEFA judgment handed down by SCA. In particular, it examines the contribution of the judgment to the doctrine of transformative constitutionalism, through the approach adopted to the interpretation of the right to basic education as well as through the contextualised analysis of the right to equality. It then interrogates the approach of the SCA in the determination of the content of the right to basic education. The Section discusses the approach of the SCA to the budgetary constraints argument raised by government in the case. Finally, the article explores the choice of the remedy in the judgment.

\section{The history of the 'Limpopo textbook saga'}

\section{(a) The context in which the 'Limpopo textbook saga' occurred'}

Before discussing the three-year history of the case, it is necessary to set out some background regarding the failure of the Limpopo Department of Education ('LDoE') to deliver textbooks to schools in the Limpopo Province. This included the revision of the schooling curriculum; the intervention in terms of Section 100 of the Constitution by the National Executive of the Limpopo provincial government; and the complete outsourcing of the procurement and delivery of textbooks to a private company called EduSolutions.

\section{(i) Curriculum change and the necessity for new textbooks}

The transition to democracy in 1994 brought with it the imperative to transform the apartheid curriculum, known as the Christian National Education Policy of 1948, which perpetuated racial discrimination and was based on a philosophy of white supremacy. ${ }^{7}$

\footnotetext{
${ }^{3} 2013$ (2) SA 40 (GNP); [2012] 3 All SA 579 (GNP).

${ }^{4}$ Section 27 and Others II Case no.24565/2012 (23 December 2012).

${ }^{5} 2014$ (4) SA 274 (GP).

${ }^{6}$ For a discussion of the history of the 2012 litigation see F Veriava The 2012 Limpopo Textbook Crisis: A Study in Rights-Based Advocacy, the Raising of Rights' Consciousness and Governance (2013) Section 27. For a broader discussion of the political context that gave rise to the 'textbook saga' see L Chisholm (note 2 above). In essence, Chisholm argues that the 'textbook saga' cannot be viewed narrowly but must be understood as symptomatic of the way the post-apartheid state functions in provinces like Limpopo and the Eastern Cape. She argues that, in these provinces, a complex web of factors that include 'already-existing social networks, practices and interests' impacts on the smooth functioning of the state bureaucracy and heighten the potential for corrupt practices. She, therefore, advocates for stronger 'national oversight' of provincial systems.

${ }^{7}$ See EB Fiske \& HF Ladd Elusive Equity: Education Reform in Post Apartheid South Africa (2005) 45.
} 
The first post-apartheid curriculum was implemented in 1998 and was known as Curriculum 2005. This was curriculum underpinned by strong social goals. It provided minimal specific content and focused instead on specifying the learning outcomes to be achieved. The rationale for this was to relate teaching directly to local contexts. ${ }^{8}$ Over the next decade, the pedagogical shortcomings of this approach would become evident. The most significant problem was the poor levels of teacher content knowledge, particularly in historically disadvantaged schools where it was often difficult for teachers to translate the outcomes specified in the curriculum into actual teaching and learning. ${ }^{9}$ The curriculum, therefore, had to be revised with an emphasis on a greater knowledge base. The product of this revision was the introduction and implementation of the Revised National Curriculum Statement (RNCS) in 2002. In 2009, a third revision occurred, resulting in the shift to the curriculum known as Curriculum and Assessment Policy Statement (CAPS).

The expert evidence of Bronwen Jill Wilson-Thompson that was relied on by the applicants in Textbooks 1 notes that, while CAPS and RNCS are similar, the purpose of CAPS was to address poor teacher content knowledge by supplementing teacher interpretation and transmission of content with the use of textbooks. CAPS-aligned textbooks were, therefore, specifically designed to 'provide clear pacing and sequencing of the curriculum content and more explicit elaboration of content to support a richer interpretation of broad curriculum statements'. ${ }^{10}$

During the course of the Limpopo textbook case, the Department of Basic Education ('DBE') argued that teachers could rely on RNCS-aligned textbooks. However, this would potentially undermine the very purpose for which CAPS was intended, which is to increase reliance on uniform textbooks, thereby minimising reliance by learners on variations in teacher content knowledge for the transmission of content. $^{11}$

In this context, the CAPS curriculum was incrementally rolled-out over a three-year period: Grades R, 1, 2, 3 and Grades 10 in 2012. In 2013, CAPS was introduced in Grades 4, 5, 6 and 11 and in 2014, it was introduced to Grades 7, 89 and 12. In the years since 2012, grades that had previously received delivery of CAPS-aligned textbooks would in theory only require 'top-ups' to their existing stocks.

\footnotetext{
${ }^{8}$ See U Hoadley Knowledge, knowers and knowing - Curriculum reform in South Africa in L Yates \& M Grumet (eds) Curriculum in Today's World: Configuring Knowledge, Identities, Work and Politics (2011) 143,145.

${ }^{9}$ The levels of poor teacher content knowledge is evident from the results of Southern and Eastern Africa Consortium for Monitoring Educational Quality ('SACMEQ III') that is a cross-national study that occurred in the period 2005-2010. The results have been analysed by Nic Spaull, an economist. According to Spaull's analysis, only 32 per cent of South African teachers had the required levels of content knowledge. Moreover, disaggregated into wealth quintiles, there appeared to be a vast difference in terms of teacher content knowledge between quintile 1 teachers and quintile 5 teachers. Teachers in the wealthier quintiles (quintile 1 and 2) were far more likely to have the requisite content knowledge than teachers in the poorer schools (quintiles 3, 4 and 5). See N Spaull, South Africa's Education Crisis: The Quality of Education in South Africa 1995-2011 33 (2013) Centre for Development Enterprise 21-25. See too N Spaull 'Poverty and privilege: Primary school inequality in South Africa' (2013) 33 Int J Educ Dev 436-47.

${ }^{10}$ Supplementary Expert Affidavit of Bronwen Jill Wilson-Thompson in Textbooks 1 Vol 6, para 7, p 855 of SCA court record in the BEFA case.

${ }^{11}$ See, for example, Textbooks 3 (note 5 above) para 50.
} 


\section{(ii) The dysfunctional state of education in Limpopo and the Section 100 intervention}

On 5 December 2011, the Limpopo Province was placed under national administration in terms of s 100 of the Constitution because of maladministration and mismanagement. This Section states:

(1) When a province cannot or does not fulfil an executive obligation in terms of the Constitution or legislation, the national executive may intervene by taking any appropriate steps to ensure fulfilment of that obligation, including-

(a) issuing a directive to the provincial executive, describing the extent of the failure to fulfil its obligations and stating any steps required to meet its obligations; and

(b) assuming responsibility for the relevant obligation in that province to the extent necessary to-

(i) maintain essential national standards or meet established minimum standards for the rendering of a service;

(ii) maintain economic unity;

(iii) maintain national security; or

(iv) prevent that province from taking unreasonable action that is prejudicial to the interests of another province or to the country as a whole.

A similar s 100 intervention was also undertaken in the Eastern Cape Province at about the same time as in the Limpopo Province. In the case of the Centre for Child Law v Minister of Basic Education ('Centre for Child Law') which dealt with failure of the Eastern Cape government to provide teachers and other non-teaching personnel to schools, the court commented on the scope of s 100. The court held that when the national sphere of government made an intervention in terms of $s$ 100(b), 'it assumes the powers of the provincial administration, and it also assumes its obligations.. ${ }^{12}$

In a statement from the DBE, the s 100 intervention in the LDoE was justified on the basis that it was meant to address the weak controls in respect of the improper running of supply chain management systems of the LDoE, the failure by the LDoE to order LTSM for the 2012 year, unpaid invoices totalling R190 million, 2400 excess teachers and 200 'ghost teachers' and the failure by the LDoE to transfer funds to schools for the day-to-day running of the school as it is required to do in terms of the norms and standards for school funding.

The statement also affirmed that it had established a task team 'to ensure that learner interests in Limpopo were not compromised.' The statement, therefore, claimed that the DBE had 'assessed how it could and should intervene to ensure that learner resources such as textbooks and stationery are delivered to schools.' ${ }^{13}$

\footnotetext{
12 [2012] 4 All SA 35 (ECG) para 8.

${ }^{13}$ Media Statement 'Joint Ministerial Team on Limpopo Section 100 intervention' <http://www.treasury.gov.za/comm media/press/2012/2012011901.pdf >.
} 
In March 2012, shortly after the intervention, the former administrator of the s 100 intervention task team produced a damning report on the state of education in Limpopo. He described the non-delivery of textbooks in Limpopo as being a 'symptom' of a system 'in a state of morass and decay. ${ }^{14}$ By the time of the intervention, the LDoE was bankrupt and had accumulated R2, 2 billion in unauthorised expenditure and had overspent its budget for the 2012/2013 financial year by R293 million.

\section{(iii) The contract with EduSolutions}

Related to the state of mismanagement within the LDoE was the fact that, in 2010, the LDoE had awarded a contract to a private company called EduSolutions for the procurement and delivery of Learner Teacher Support Materials (LTSM) in the Limpopo Province. In terms of this contract, EduSolutions took over the entire textbook procurement process. EduSolutions was to receive, process, place orders, effect payment and effect delivery of all textbooks as specified in the contract. It would negotiate discounts with publishers. It would comply with the delivery timelines specified in the contract. The effect of this was that the entire process for the procurement and delivery of textbooks had been entirely outsourced. The LDoE book unit was at this point disbanded and the entire database containing the list of schools in the province was handed over to EduSolutions. When the EduSolutions contract was cancelled, the DBE's ability to deliver textbooks in Limpopo was severely affected by the absence of the database, since it did not have a list of all the schools in the Limpopo Province. ${ }^{15}$

The budget for the 2011/2012 school year for textbooks was R126 million. However, the amount in terms of the contract with EduSolutions for textbooks was R343 million. This amount to be paid to EduSolutions far exceeded the budget for textbooks. EduSolutions would later allege that it failed to place any orders for any textbooks for the 2012 academic school year because of an outstanding payment of approximately R21 million that was owed to it by the LDoE. ${ }^{16}$

The contract with EduSolutions was terminated on 26 April 2012 on the basis that it was irregular. It is worth noting that Kollapen $\mathrm{J}$ in Textbooks 1 described the tender as being an 'unscrupulous tender award'. ${ }^{17}$

It was in this context of the nationwide curriculum revision, a general malaise of the education system in the Limpopo Province and the fact that, by the time the litigation was instituted in early May 2012, the order for textbooks to publishers had still not been placed. The stage was set for the Limpopo textbook litigation to occur.

\footnotetext{
${ }^{14}$ See Letter and Administrative Report Education Report Textbooks 1 Vol 5, pp 680-694 of SCA court record in the $B E F A$ case.

${ }^{15}$ See DBE's Answering Affidavit in Textbooks 1 para 29.

${ }^{16}$ DBE's Answering Affidavit in Textbooks 1 paras 28-31.

${ }^{17}$ Textbooks 1 (note 3 above) para 17.
} 


\section{(b) The litigation}

\section{(i) Textbooks 1}

At the beginning of 2012, Section 27 initiated an investigation into the non-delivery of textbooks at schools in the Limpopo Province by visiting several schools in Province. ${ }^{18}$ Each of the schools visited confirmed that textbooks had not yet been delivered, and that there was no indication as to when delivery would occur because schools had received no communication from the LDoE in this regard. Poor communication between the LDoE and schools would feature strongly throughout the Limpopo textbook case. The Metcalfe verification report, which is discussed later, made the finding that Limpopo schools had the 'poorest communication infrastructure' and that communication on the non-delivery of textbooks had been very poor. It therefore recommended that 'rapid and efficient mechanisms' such as SMS notifications be put in place as a matter urgency to communicate to schools. ${ }^{19}$

On 28 February 2012, Section 27 addressed a letter to the DBE and the LDoE, indicating its concerns that textbooks had not been delivered and requesting an indication as to when textbooks would be delivered to Limpopo schools. Media reports up to then reflected on undertakings by the DBE that delivery of the textbooks was imminent and that a 'minimum of disruptions' was to be expected. What followed was a paper trail of unfulfilled undertakings and broken promises to Section 27 as to when textbook delivery would occur. ${ }^{20}$

On 4 May 2012, therefore, when learners had been without textbooks for almost half the year and were about to sit for the June examinations without textbooks that would enable them to prepare for exams, Section $27^{21}$ together with two co-applicants launched an urgent application. The Centre for Applied Legal Studies (CALS) acted as the attorneys of record in the matter. The second applicant was Hayani Thomo Secondary School, a secondary school in Limpopo that had not received any textbooks for the 2012 academic year. The third applicant was Tandani Lydia Msipiphethetu, a mother of two learners at Lutandale Primary School in Grades 6 and 3, respectively. Neither of her two children had been provided with textbooks for the 2012 academic year. She alleged that, without textbooks she was struggling to assist her children with their schoolwork.

The Minister of Education as head of the DBE and the MEC for Education in Limpopo were cited as the first and second respondents, respectively. Given the s 100 intervention and the assumption of the obligations of the LDoE by the DBE, this

\footnotetext{
${ }^{18}$ The investigation was initiated following media reports that schools in the province had not received their textbooks at the beginning of the academic year.

${ }^{19}$ M Metcalfe 'Verification of textbook deliveries in Limpopo' (2012) 4 <http://www.gov.za/sites/www.gov.za/files/ textbooks.pdf $>$.

${ }^{20}$ The chronology of these events is set out in F Veriava (note 6 above) ii-iii. It is worth noting, for example, that, despite an undertaking given by DBE representatives in early meetings that all textbooks would be delivered by midApril, it was only in late April and after a final letter of demand had been sent that a bidding process between book publishers was initiated.

${ }^{21} \mathrm{Adv}$ Adila Hassim, who served as counsel in all of the textbook cases notes that Section 27 became the main applicant for two reasons. Firstly, departmental officials had intimidated many of the staff at the schools that Section 27 had been dealing with. These schools, therefore, needed to be protected by an 'institutional client'. Secondly, Section 27 was 'best placed to provide direct and credible evidence of the state of the textbook shortages', given their visits to many of the schools. A Hassim Twenty Years of Constitutionalism - The Right to Education: A Textbook Case (2014) 4.
} 
article refers mainly to the $\mathrm{DBE}$ as the respondent party in the litigation. The case was heard on 15 May 2012 in the North Gauteng High Court.

The applicants sought the delivery of textbooks to Grades R, 1, 2, 3 and 10 by 31 May 2012. A highly innovative remedy was also devised in which the applicants required that the state develop a 'catch up' plan for Grade 10's in the Limpopo province together with a supervisory order requiring that the DBE report to the court, on a monthly basis, the progress in respect of the catch-up plan. ${ }^{22}$

The judgment was handed down on 17 May 2012. Kollapen J found that the failure to provide textbooks to Limpopo schools constituted a violation of the right to basic education in terms of s 29(1)(a); the right to equality in terms of s 9; the right to dignity in terms of s 10; certain provisions of the South African Schools Act ('SASA') and, finally, s 195 of the Constitution that sets out the basic values and principles governing public administration.

In the context of a finding of a violation of the right to basic education, Kollapen J held that textbooks are an 'essential' component of the right to a basic education, and therefore a pre-requisite for the fulfilment of the right. He noted: ${ }^{23}$

[T]he provision of learner support material in the form of textbooks, as may be prescribed is an essential component of the right to basic education and its provision is inextricably linked to the fulfilment of the right. In fact, it is difficult to conceive, even with the best of intentions, how the right to basic education can be given effect to in the absence of textbooks.

Kollapen J, therefore, ordered the DBE to deliver textbooks to learners in Grades R, 1, 2, 3 and 10 on an urgent basis, commencing 31 May 2012 and concluding no later than 15 June 2012. He also directed the DBE to develop a 'catch-up plan' for learners in Grade 10 and provided guidelines that established the parameters for compliance with such a plan. Finally, he granted the applicants relief that they be entitled to approach the court on the same papers for further relief, relief that with hindsight, proved to be invaluable. Neither delivery nor the catch-up plan occurred as set out in a court order, compelling the applicants to return to court on two subsequent occasions in 2012.

On 5 July 2012, after Section 27 raised concerns relating to the non-compliance with the order in Textbooks 1, the parties avoided further court action and reached a settlement that was made an order of court. Despite the court order, inaccurate reports as to the status of textbook delivery persisted. Section 27 and the DBE therefore agreed to the appointment of Professor Mary Metcalfe, the former MEC for Education in Gauteng, as an independent person to verify the contents of the progress reports and to assess the status of textbook delivery to schools.

The report found that DBE had failed to meet the re-negotiated deadline of 27 June 2012 for the completion of delivery. The report indicated further that, on 28 June 2012, 'very few of the textbooks had reached schools'. Of the 411 schools sampled by the task team, it was found that on, 27 June 2012, only 15 per cent schools had

\footnotetext{
22 The rationale for the catch-up plan was to place learners in the position they would have been in had they had the necessary textbooks for the entire academic year. Thus, what was required was a programme that would facilitate a revision of the content of the syllabi in all subjects that had been covered in the first half of the academic year.

${ }^{23}$ Textbooks 1 (note 3 above) para 25.
} 
received their textbooks; on 3 July 2012, 48 per cent of schools had received their textbooks; and on 11 July 2012, 22 per cent were still awaiting delivery of textbooks. ${ }^{24}$

Professor Metcalfe made extensive recommendations related to addressing systemic failures in textbook delivery in Limpopo, including that the DBE conduct a full audit of the state of textbook delivery. This, however, did not occur. The BEFA judgment makes the point that: 'It is common cause that Professor Metcalfe's recommendations were not implemented.' 25

\section{(ii) Textbooks 2}

In September 2012, amidst continuing reports of non-delivery, the applicants again returned to court. Section 27 was concerned that the DBE had failed to comply with two previous court orders and some schools had not received textbooks by the third term. In addition, there was the awareness that the CAPS curriculum was to be implemented for learners in Grades 4, 5, 6 and 11 in 2013. At that stage, it was not clear whether there were funds available for the procurement of these books.

The applicants, therefore, sought an order this time round declaring that the DBE had failed to comply with the two previous court orders; that the DBE conduct an independent verification process to determine which schools in Limpopo had received textbooks for the academic year 2012; that the DBE deliver all outstanding textbooks for 2012 and complete the delivery of textbooks for all grades for the academic year 2013 by no later than 9 January 2013 and develop catch-up plans in compliance with the first and second court orders.

On 4 October 2012, Kollapen J handed down his second judgment in the Limpopo textbook case. He made an order declaring that the DBE had failed to comply with two previous court orders. He said: ${ }^{26}$

[T] he deadlines for the delivery of 15 June and then 27, were dates that the respondents had offered and when they were so offered, there was the expectation that those deadlines would be met. That they were not met is unfortunate and distressing, particularly in a country where educational competence in areas of numeracy and literacy [lag] far behind international standards and in a province where numeracy/literacy levels [lag] considerably behind national standards.

He also found that there was non-compliance in respect of the catch-up plan. However, while he found that an independent verification process 'may be the most ideal mechanism to deal with outstanding delivery', he was concerned about the 'practical effect and value', given that it was already the end of the academic year. ${ }^{27} \mathrm{He}$ therefore ordered the DBE to complete the entire 2012 textbook delivery by 12 October 2012 and all textbook delivery for 2013 by 13 December 2012. He further required that the DBE provide affidavits specifying details relating to the catch-up plan and to the 2013 textbook delivery.

\footnotetext{
${ }^{24}$ Metcalfe Verification Report (note 18 above) 43-45.

${ }^{25}$ BEFA (note 1 above) 15.

${ }^{26}$ Textbooks 2 (note 4 above) para 9.

${ }^{27}$ Textbooks 2 (note 4 above) para 20.
} 
By 14 December 2012, textbook delivery for the following 2013 academic year was more or less complete even though there continued to be reports of non-delivery at some schools. ${ }^{28}$ The DBE did not appeal either Textbooks 1 or Textbooks 2.

\section{(iii) Textbook 3}

In March 2014, a new urgent application was launched, this time by a communitybased organisation called Better Education for All (BEFA) and a number of Limpopobased schools. This time around Section 27 served as the applicants' attorneys. BEFA is an organisation that had its genesis in the 2012 textbook litigation. Adila Hassim, the head of litigation at Section 27 and counsel in all three cases, described the emergence of BEFA in the following terms: ${ }^{29}$

Due to national attention that the textbook case received, parents and teachers in Limpopo began to mobilise. Indeed the monitoring of the first court order, the settlement order and the third court order were possible because teachers, principals and parents began to alert Section27 to shortages in delivery more systematically. In 2013, a movement of community members began - called Better Education for All (BEFA).

Thus, at the beginning of 2014, amidst reports of textbook shortages from BEFA, Section 27 began supplying the DBE with lists of textbook shortages at identified schools. However, the DBE consistently failed to remedy these shortages. It is worth mentioning that, during the high court case there was a dispute as to the exact shortfall in the delivery of textbooks. On the DBE's own version there was a shortage of 22,045 textbooks across all grades at the applicant schools. The applicants averred the figure was much higher. This dispute was never resolved, but it did not have any impact on the finding that government had failed to fulfil its obligations. ${ }^{30}$

The applicants, therefore, sought an order declaring that the failure to deliver textbooks to the 39 schools timeously constituted a violation of the learners' rights at those schools, in particular, the right to basic education. They also sought to make an agreed-upon deadline for the delivery of the textbooks to the schools an order of court. Finally, the applicants again sought supervisory relief requiring government to report to the court on textbook delivery, and to lodge with the court a plan indicating how it intended to address textbook shortages at all schools in Limpopo. The court was also asked to direct the South African Human Rights Commission (SAHRC) to monitor both, textbook delivery to the affected schools and the DBE's compliance with the plan.

In court, the DBE argued that, because textbook delivery for 2014 had largely been completed, the failure to deliver textbooks to a small number of affected schools did not constitute a violation of the learners' rights. This, according to them, made the case distinguishable from the 2012 situation, when delivery at the majority of Limpopo schools had not taken place. The DBE's basic contention for the shortages at the 39 schools was that late deliveries were caused by budgetary constraints and the failures

\footnotetext{
${ }^{28}$ Press Statement Section 27 'Update on Textbook delivery for 2013' <http://section27.org.za/wp-content/uploads/ 2012/12/press-statement-update-of-textbook-delivery-14-Dec-2012.pdf > .

${ }^{29}$ A Hassim (note 21 above) 10.

${ }^{30}$ See BEFA (note 1 above) para 17.
} 
by the principals of certain schools to submit returns identifying needs not initially anticipated'. ${ }^{31}$

On 7 May 2014, Tuchten J delivered his judgment. He confirmed and elaborated on the finding in Textbooks 1 in respect of the centrality of textbooks in the realisation of learners' rights. ${ }^{32}$ The judgment then went a step further by stating that it is the right of every learner to be provided with textbooks before the teaching of the curriculum for which such textbooks are prescribed is due to commence. Tuchten $J$ further declared that the failure by government to do this is a violation of the rights - to basic education, equality and dignity of the affected learners. He stated: ${ }^{33}$

The delivery of textbooks to certain learners but not others cannot constitute fulfilment of the right. Section 29(1)(a) confers the right of a basic education to everyone. If there is one learner who is not timeously provided with her textbooks, her right has been infringed. It is of no moment at this level of enquiry that all other learners have been given textbooks.

Tuchten J, however, refused to make the agreement between the parties in respect of the delivery date for textbooks an order of court. This was despite the 2012 experience of government's non-compliance with court-ordered dates for textbook delivery and evidence suggested that, at some schools, textbooks for 2012 and 2013 had not been delivered. ${ }^{34}$

The judgment also rejected the supervisory relief sought. In respect of the SAHRC's role in such supervision, this was justified largely on the basis that the SAHRC had claimed that they did not have the capacity to undertake the monitoring requested. Instead Tuchten J made an order requiring government to report to the applicants and the SAHRC the details of its 'submissions for funds for textbooks for the academic year 2015', which it was to have to the relevant fiscal authorities.

The judgment was appealed by the DBE and cross-appealed by BEFA. The basis of the DBE's appeal was that Tuchten J erred in finding that a full complement of textbooks is necessary to provide a basic education. The DBE's argument was that this requirement is tantamount to a 'standard of perfection' that should not be applied to determine whether or not there has been a breach of the right. The DBE argued further that such a standard was equivalent to imposing a minimum core obligation on government, a standard which had been rejected by the Constitutional Court in Mazibuko $v$ City of Johannesburg ('Mazibuko'). ${ }^{35}$ Instead, the DBE argued that the requisite standard ought to be whether or not government has taken all reasonable steps or measures to fulfil the right. The DBE also appealed the relief granted by Tuchten $\mathrm{J}$ on the basis that it was not the relief sought by the applicants.

BEFA cross-appealed on the following two grounds, firstly, that Tuchten J had erred in not finding that there had been non-compliance with the first two court orders; and secondly, it appealed the failure to grant supervisory relief. This latter aspect of the cross-appeal was later abandoned. This is discussed later.

\footnotetext{
${ }^{31}$ Textbooks 3 (note 5 above) para 44.

32 lbid para 51.

33 lbid para 52.

${ }^{34}$ BEFA heads of argument in the SCA appeal paras 81-85.

${ }^{35}$ (2010) 4 SA 1 (CC) para 61.
} 


\section{An analysis of the BEFA judgment in the SCA}

The hearing before the SCA was on 24 November 2015 and the unanimous judgment of the SCA was handed down on the 2 December 2015. The tone and unequivocal condemnation of the conduct of the DBE in the judgment were unsurprising given that, on the day of the hearing, the counsel for the DBE was subjected to an intense 'grilling' by the SCA justices as to the merits of the DBE's appeal. ${ }^{36}$

The judgment is instructive in several respects. The most significant aspect of the $B E F A$ judgment is that it is demonstrates the transformative potential of South Africa's Constitution. ${ }^{37}$ This transformative thread that guides and permeates the BEFA judgment lays a firm foundation for the approach adopted by the SCA in interpreting the right to basic education and the right to equality, which respectively are discussed below.

\section{(a) A 'transformative narrative' for the right to basic education}

The BEFA judgment regards the enjoyment of the right to basic education as being necessary for the broader transformation of South African society. It therefore confirms the 'immediate realisation' principle that has been adopted in South Africa's lower courts in respect of education provisioning. Furthermore, by confirming that textbooks are an essential component of the right to basic education, the BEFA judgment adopts a substantive approach to interpreting the right, albeit cautiously.

\section{(i) The right to education as an 'empowerment right'}

The BEFA judgment begins by drawing the connections between broader education struggles for students to 'realise their full potential,' such as the recent countrywide protests at tertiary institutions for access to higher education. ${ }^{38}$ It cites relevant Constitutional Court jurisprudence that emphasises the transformative potential of the right to basic education, ${ }^{39}$ such as the case of Governing Body of the Juma Musjid Primary School v Ahmed Asruff Essay NO (Juma Musjid). ${ }^{40}$ This was a case in which a private property owner successfully sought to evict a public school established on its property; the court went beyond the strictures of that case, and, indeed, to some lengths, to comment on the state's obligations to protect the right to basic education.

\footnotetext{
${ }^{36}$ See F Rabkin 'Judges grill department over Limpopo textbook failures' Business Day <http://www.bdlive.co.za/ national/education/2015/11/25/judges-grill-department-over-limpopo-textbook-failures $>$. Franny Rabkin notes that counsel for the DBE was 'interrupted' by Navsa J who said he was "'struggling to understand" the state defence'. Later Navsa J asked whether the DBE should not, "' on sober reflection", just say "mea culpa" instead of shifting the blame to everyone else'.

${ }^{37}$ Karl Klare in his seminal study on 'transformative constitutionalism' describes the role of the Constitution in the transformation in the following terms: '[A] long-term project of constitutional enactment, interpretation and enforcement committed (not in isolation, of course, but in historical context of conducive political developments) to transforming a country's political and social institutions and power relationships in a democratic, participatory and egalitarian direction. Transformative constitutionalism connotes an enterprise of inducing large-scale change through non-violent political processes grounded in law. KE Klare 'Legal Culture \& Transformative Constitutionalism' (1998) 14 SAJHR 146,150.

${ }^{38}$ BEFA (note 1 above) para 3.

39 lbid para 37.

${ }^{40}$ 2011(8) BCLR 761 (CC).
} 
In Juma Musjid, the Court, quoting from General Comment 13 to the International Covenant on Economic, Social and Cultural Rights (ICESCR), stated: ${ }^{41}$

Education is both a human right in itself and an indispensable means of realising other human rights. As an empowerment right, education is the primary vehicle by which economically and socially marginalized adults and children can lift themselves out of poverty and obtain the means to participate fully in their communities. Education has a vital role in empowering women, safeguarding children from exploitation and hazardous labour and sexual exploitation, promoting human rights and democracy, protecting the environment, and controlling population growth. Increasingly, education is recognised as one of the best financial investments States can make. But the importance of education is not just practical: a well-educated, enlightened and active mind, able to wander freely and widely, is one of the joys and rewards of human existence.

Indeed the BEFA judgment is strewn with references to the transformative potential of basic education. The following statement most succinctly encapsulates the SCA's approach to the right to basic education:

It cannot be emphasized enough that basic education should be seen as a primary driver of transformation in South Africa.

In doing this, the BEFA judgment locates the right to basic education in its widely acknowledged role as an 'empowerment right', that is, it is a precondition for the enjoyment and exercise of other rights and freedoms. ${ }^{42}$

The judgment further seeks to determine the content of the right and, in so doing, bucks a trend in South Africa's socio-economic rights jurisprudence which has been towards 'normative emptiness' and which has come under the criticism of legal scholars. $^{43}$

There exists a vast South African legal scholarship that acknowledges the transformative potential of the Constitution, including, through the entrenchment of socioeconomic rights and the adoption of a substantive approach to the right to equality. ${ }^{44}$ However, it simultaneously bemoans elements of conservatism in South Africa's legal culture, particularly in its tradition of analysis, ${ }^{45}$ including in its emerging socioeconomic rights jurisprudence.

\footnotetext{
${ }^{41}$ Ibid para 41.

${ }^{42}$ See for example F Veriava \& F Coomans 'The right to education' in D Brand \& C Heyns (eds), Socio-Economic Rights in South Africa (2005) 57-83. See too of Madzodzo v Minister of Basic Education [2014] 2 All SA 339 (ECM), 2014 (3) SA 441 (ECM) para 18.

${ }^{43}$ See for example the work of David Bilchitz, a proponent of minimum core. D Bilchitz 'Giving Socio-Economic Rights Teeth: The Minimum Core and Its Importance' (2002) 119 SAL 484; D Bilchitz 'Towards a Reasonable Approach to the Minimum Core: Laying the Foundations for Future Socio-Economic Rights Jurisprudence' (2003) 19 SAJHR 1; D Bilchitz 'Avoidance remains avoidance: Is it desirable in socio-economic cases?' in S Woolman (ed) Constitutional Court Review (2014) 297; S Sibanda 'Not Purpose-Made! Transformative Constitutionalism, Post-Independence Constitutionalism and the Struggle to Eradicate Poverty' (2011) 22 Stell LR 482.

${ }^{44}$ KE Klare (note 37 above) 146. P Langa 'Transformative Constitutionalism' (2006) 17 Stell LR 351; D Moseneke 'The Fourth Bram Fischer Memorial Lecture: Transformative Adjudication' (2002) 18 SAJHR 309; S Sibanda Ibid 487; J Brickhill \& Y van Leeve 'Transformative Constitutionalism - Guiding light or empty slogan?' in A Price \& M Bishop (eds) A Transformative Justice: Essays in Honour of Pius Langa (2015) 141.

${ }^{45}$ K Klare Ibid 169. K van Marle 'Transformative Constitutionalism as/and Critique' (2009) 20 Stell LR 286, 290.
} 
Legal scholars critical of the judiciary's approach to socio-economic rights adjudication accuse the judiciary of having embraced a form of 'judicious avoidance'. ${ }^{46}$ Much of the critique in respect of the socio-economic rights jurisprudence has centred on the adoption by the courts of an approach termed 'reasonableness review' as the standard for adjudicating socio-economic rights cases, rather than a more substantive approach to the adjudication of such cases.

'Reasonableness review' has been adopted by the Constitutional Court in respect of socio-economic rights such as health, housing, food, water and social security. ${ }^{47}$ These rights are qualified by the terms 'reasonable legislative and other measures', within the state's available resources and 'progressive realization'. Courts adjudicating cases in respect of these rights merely have to determine whether or not government has put in place reasonable programmes to progressively realise the right under review. ${ }^{48}$ This is as opposed to determining whether or not an individual has a direct claim in respect of the right, which then, of necessity, also requires that a court determine the content of the right. ${ }^{49}$

In essence, critics of 'reasonableness review' argue that this technique of socioeconomic rights adjudication is procedural in nature, and therefore normatively empty. ${ }^{50}$ They describe 'reasonableness review' as being a 'narrow adjudicative

\footnotetext{
$46 \mathrm{~J}$ Dugard 'Courts and structural poverty in South Africa: To what extent has the Constitutional Court expanded access and remedies to the poor?' in D Bonilla Maldonado (ed) Constitutionalism in the Global South: The Activist Tribunals of India, South Africa, and Columbia (2012) 293. See too D Bilchitz (note 43 above).

47 The jurisprudence in respect of 'reasonableness 'review' has been developed in the following cases. In Soobramoney $v$ Minister of Health, KwaZulu Natal (Soobramoney) 1998 (1) SA 765 (CC) the Court held that a state hospital decision not to provide dialysis for a patient in terms of developed guidelines was not unreasonable and was applied rationally and in good faith. In Government of the Republic of South $v$ Grootboom (Grootboom) 2001 (1) SA 46 (CC) the Court held that the failure of a government programme to provide a homeless community with shelter was unreasonable and, as such, violated the right to housing. In Minister of Health $v$ Treatment Action Campaign (TAC) 2002 (5) SA 721(CC) the Court held that the government decision to restrict the use of the anti-retroviral drug neviripine to selected pilot sites in its mother-to-child programme to prevent HIV was unreasonable and as such, violated the right to healthcare. In Khosa v Minister of Social Development (Khosa) 2004 (6) SA 505 (CC) the Court held that the Social Assistance Act excluding permanent residents from access to social assistance grants was unreasonable, and, as such, violated the right to social security. In Mazibuko (note 35 above) the Court held that the City of Johannesburg Free Basic Water Policy and its installation of pre-paid water metres pursuant to that policy were not unreasonable and, as such, the right to water was not violated.

${ }^{48}$ The Constitutional Court's socio-economic rights jurisprudence has identified the essential elements state programmes must exhibit for it to be reasonable: it must be capable of facilitating the realisation of the right. It must be comprehensive, coherent and co-ordinated. Appropriate financial and human resources must be made available for the programme. It must be balanced and flexible and make appropriate provision for short, medium and long-term needs; it must be reasonably conceived and implemented. It must be transparent, and its contents must be made known effectively to the public. It must make short-term provision for those whose needs are urgent and who are living in intolerable conditions. See for example S Liebenberg Socio-Economic Rights - Adjudication Under a Transformative Constitution 1st ed (2010) 152-53.

${ }^{49}$ The embracing of reasonableness review in assessing the positive obligations in respect of the qualified socioeconomic rights occurred in the context of the Constitutional Court's rejection of the minimum core in its health and housing cases. The notion of 'minimum core' or the 'core content' of socio-economic rights arises from the General Comment 3 of the United Nations Committee on Economic Social and Cultural Rights (CESCR). Minimum core is generally employed in international human rights law in respect of qualifications inherent in the entrenchment of socio-economic rights so as to ensure that nation states provide the minimum essential levels in respect of those rights and do not just attribute failures in respect thereof to budgetary constraints.

${ }^{50}$ See note 43 above.
} 
technique that has become the default position in a conservative legal culture'. ${ }^{51}$ Critics suggest further that this approach limits the transformative potential of having a justiciable set of socio-economic rights that could address issues of structural inequality. ${ }^{52}$

Some of South Africa's foremost scholars on socio-economic rights have therefore attempted to address this by advocating for a more substantive approach to socio-economic rights interpretation. ${ }^{53}$ The BEFA judgment's embrace of a substantive approach in respect of the right to basic education is therefore noteworthy.

\section{(ii) The 'immediate realisation' principle as contributing to a 'transformative narrative'}

Robert Cover, in his article on the creation of legal meaning, uses the term 'redemptive constitutionalist narrative', which he deems as necessary for transformation to occur. ${ }^{54}$ He notes further that a court as 'supreme interpreter of the law' may legitimate the redemptive constitutionalist narrative and thereby create alternative legal meaning, or it may adopt a static juridical position. The BEFA judgment embraces such a 'redemptive' or to describe it differently, a 'transformative constitutionalist narrative' that is imperative to the transformation of basic education.

In particular, the BEFA judgment confirms that the right as an unqualified socioeconomic right is distinguishable from the other qualified socio-economic rights in the South African Constitution and is therefore 'immediately realisable'. In doing this it again draws on the often quoted passage from Juma Musjid that notes: ${ }^{55}$

It is important, for the purpose of this judgment, to understand the nature of the right to 'a basic education' under section 29(1)(a). Unlike some of the other socio-economic rights, this right is immediately realisable. There is no internal limitation requiring that the right be 'progressively realised' within 'available resources' subject to 'reasonable legislative measures'. The right to a basic education in section 29(1)(a) may be limited only in terms of a law of general application which is 'reasonable and justifiable in an open and democratic society based on human dignity, equality and freedom'. This right is therefore distinct from the right to 'further education' provided for in section 29(1)(b). The state is, in terms of that right, obliged, through reasonable measures, to make further education 'progressively available and accessible'. (Own emphasis).

\footnotetext{
${ }^{51}$ D Biltchitz (note 43 above) 298.

52 S Sibanda (note 43 above) 486.

53 Sandy Liebenberg, for example, appears to advocate for an approach that marries 'reasonableness review' with a more substantive approach. She puts forward an approach for the future adjudication of qualified socio-economic rights that appears to embrace both reasonableness and an interpretation of socio-economic rights that includes the determination of the scope and content of the right for the assessment of reasonableness. Such a determination of the normative content of the right would, according to her, take into account 'the purpose and values which the particular rights are intended to promote, paying careful attention to the relevant historical and social contexts and disadvantaged group's articulations of their needs and measures needed to fulfil them'. S Liebenberg (note 48 above) 171. This may be compared to David Bilchitz, who has developed what he describes as an 'interest based approach' that aims to protect the interests of individuals based on their different levels of poverty and, accordingly, the urgency of their needs. He, therefore, distinguishes between two levels of interest. The first is a 'minimal interest' that persists with, and is akin, to a minimum core approach. This approach requires the imposition on government of an unconditional obligation to provide the basic necessities to ensure survival. The second is what he terms a 'maximal second interest', to ensure the socio-economic conditions necessary to attain a wider range of purposes. D Bilchitz Poverty and fundamental rights: The Justification and Enforcement of Socio-Economic Rights (2007).

${ }^{54}$ RM Cover 'The Supreme Court, 1982 Term - Forward: Nomos and Narrative' (1983) 97 Harv L Rev 4, 34.

55 Juma Musjid (note 40 above) para 37. See BEFA (note 1 above) paras 36-37, 44.
} 
The holding in Juma Musjid was also applied in the case of Madzodzo v Minister of Basic Education (Madzodzo). ${ }^{56}$ This is also an education provisioning case that deals with the systemic failure of government to provide desks and chairs to schools in the Eastern Cape. During a third round of litigation in the case, which related to the deadline for the furniture delivery, one of the arguments made by the DBE was that it need-not deliver the desks and chairs within a specific time frame; instead, all it required to do was to show progress in furniture delivery and that it had a reasonable plan for such delivery.

Goosen J rejected these arguments. He found that, flowing from the right to basic education, the government was required to take 'all reasonable measures to realise the right to basic education with immediate effect. This requires that all necessary conditions for the right to education be provided'. (Own emphasis.) ${ }^{57}$

Thus, the BEFA case confirms these earlier judgments that government is under a direct, or immediate duty, to provide a basic education, unlike as in the case of the qualified socio-economic rights. This adoption of the 'immediate realisation' principle by the SCA runs counter to the arguments by the DBE in the education provisioning cases that the right to basic education is a right to be 'progressively realised'. ${ }^{58}$

A survey of the basic education legal framework suggests that government has consistently adopted this incrementalist approach in respect of its obligations to fulfil the right to basic education. That is, despite the fact that the right to basic education is framed differently from other socio-economic rights, the DBE has interpreted the right as a right to be 'progressively realised'. An example of this was noted in government's own 'Twenty Year Review of Disability in South Africa', developed within the Office of the President of South Africa that attributed the failure to adequately provide for learners living with disabilities to an 'incrementalist stance' adopted by government to the implementation of policy. The Twenty Year Review noted further that such an incrementalist stance' is inconsistent with the obligation to 'immediately realise' the right to basic education for learners with disabilities. ${ }^{59}$

Further evidence of such an 'incrementalist stance' is the 'Declaration' or, rather, the reservation which the South Africa government included with the country's ratification to the International Covenant on Economic, Social and Cultural Rights (ICESCR) 20 years after signing it. The Declaration states: ${ }^{60}$

The Government of the Republic of South will give progressive effect to the right to education, as provided for in Article 13 (2)(a) and Article 14, within the framework of its National Education Policy and available resources. (Own emphasis.)

\footnotetext{
${ }^{56}$ Madzodzo (note 42 above).

57 Ibid para 17.

${ }^{58}$ According to McConnachie \& McConnachie, the developing approach to the right is to view the right as an 'entitlement to a good rather than an action'. C McConnachie \& C McConnachie 'Concretising the Right to a Basic Education' (2012) 129 SALJ 554, 564.

${ }^{59}$ The Presidency 'Twenty Year Review South Africa 1994-2014 - Background Paper: Disability'(2014). A similar characterisation of the problem is also articulated in the baseline country report produced by the South African government on the implementation of the CRPD in South Africa. <http://accesstech.co.za/wpcontent/uploads/2014/06/ 12percent20Disability_20YR.pdf $>$. See too Department of Women, Children \& People with Disabilities, Baseline country report to the United Nations on the implementation of the Convention on the Rights of Persons with Disabilities in South Africa (2013) 28.

${ }^{60}$ South Africa: Ratification UN Depositary Notification C.N 23.2015.Treaties - IV.3 <https://treaties.un.org/doc/ Publication/CN/2015/CN.23.2015-Eng.pdf >.
} 
In contrast to government's approach, what appears to be intended by the court judgments so far in respect of the 'immediate realisation' principle is that the essential components that make up the right are identified and that government takes all reasonable steps to provide these essential components with 'immediate effect'. This approach is necessary to ensure that each and every child can enjoy the right to basic education. This is because, to the extent that even a single learner may be deprived of a quality education, the consequences for that particular learner may be irreversible.

\section{iii. The absence of an objective test for determining the content of the right}

Having determined that the right to basic education is 'immediately realisable', the $B E F A$ judgment goes on to note that textbooks constitute one of the entitlements that make up the right to basic education. ${ }^{61}$ As such, the SCA adopts a substantive approach to interpreting the right and, in so doing, confirms the judgments in Textbooks $1^{62}$ and Textbooks $3 .^{63}$

Such a substantive approach was also alluded to in Juma Musjid. ${ }^{64}$ It was also adopted by the lower courts in $M a d z o d z o^{65}$ and, more recently, in the case of Tripartite Steering Committee $v$ Minister of Basic Education ('Tripartite Steering Committee'). ${ }^{66}$ In the latter case, the Eastern Cape High Court had to determine whether the right to basic education includes a direct entitlement right to be provided with transport to and from school at government expense for those learners who live a distance from school and who cannot afford the cost of transport. The court concluded that it did. Somewhat less explicitly, the Eastern Cape High Court has, through a string of post-provisioning cases suggested that teaching and non-teaching posts in schools are further entitlements in respect of the right to basic education. While many of these cases were settled out of court, in those cases where judgments were delivered, the Court held that the failure to declare post-establishments and appoint teaching and non-teaching personnel for schools constitutes a violation of the right to basic education. $^{67}$

However, while the BEFA judgment constitutes an endorsement of a substantive approach to socio-economic rights adjudication, the SCA stopped short of developing an objective test for determining the necessary entitlements that make up the content of the right and instead suggests that it is government's discretion to determine this.

The main argument put forward by government for its failure to ensure full textbook provisioning to each and every learner has been that, while the aim of its stated policy was that every learner be provided with a textbook, the failure to meet this

\footnotetext{
${ }^{61}$ BEFA (note 1 above) para 41 and para 50. Both BEFA and the SAHRC provided extensive evidence in their heads of argument as to the benefit of the use of textbooks.

${ }^{62}$ Note 23 above.

${ }^{63}$ Note 33 above.

${ }^{64}$ In Juma Musjid, the Constitutional Court describes 'access' as one of the essential components of the right to basic education. Implicit in this statement is the assumption that there is a basket of entitlements or components that make up the right. See Juma Musjid (note 40 above) para 43.

${ }^{65}$ Madzodzo (note 42 above) para 20.

${ }^{66} 2015$ (5) SA 107 (ECG).

${ }^{67}$ See Centre for Child Law (note 12 above) paras 32-34. See too Linkside v Minister of Basic 'Linkside' 3844/2013 [2015] ZAECGHC (26 January 2015) para 2. For a discussion of the history of these cases see Legal Resources Centre, Ready to Learn? A Legal Resource for Realising the Right to Education (2013) 67-68 and Legal Resources Centre Fighting to Learn - A Legal Resource for Realising the Right to Education (2015) 55-63.
} 
objective could not be construed as a violation of a constitutional right. To do so, it argued, was to hold the DBE to an impossible 'standard of perfection'. ${ }^{6}$

The SCA vociferously rejected this argument and held instead that government through its 'policy and actions ${ }^{69}$ had itself determined the content of the right, which included that every learner be provided with a textbook. The SCA's view, therefore, is that government must in fact hold itself to the standard that it has set for itself. ${ }^{70}$

This approach may be too cautious and may serve in time to undermine the substantive path that the BEFA judgment seemed resolved to embark on. It should rather have laid a foundation for the development of an objective test for determining whether or not a particular educational resource, in this instance textbooks, should be regarded as necessary for the fulfilment of the right. ${ }^{71}$

In Textbooks 3, while Tuchten J confirmed Kollapen J's approach, which relied primarily on the policies of the executive in confirming that textbooks were a component of the right, he simultaneously issued a warning against relying on the existence of such policies as a basis for determining the content of the right. He noted: 'I wish to guard myself against the proposition that the content of a right may be determined without more by reference to the policies of the executive. ${ }^{72}$

Thus, it is submitted that, while the deference shown to the other arms of government did not have a detrimental impact on the outcome of the applicants case in this instance, the absence of an objective test could impact on future education provisioning cases, particularly where there is a lack of clarity from the government as to its policy and provisioning. Indeed, by making government policy the sole determinant of the content of the right, government will be disincentivised from providing policy certainty in respect of education provisioning. Already, there is evidence of this in other areas of education provisioning. ${ }^{73}$

Moreover, given the widely acknowledged crisis in basic education, particularly in under resourced and historically disadvantaged schools, there are compelling reasons

\footnotetext{
${ }^{68}$ Franny Rabkin notes that, at the hearing, counsel for the DBE argued that, while it was the state's 'aim' that every learner be provided with a textbook, if that aim was not achieved, while, for some learners, not having textbooks 'may create some inconvenience', this could not be construed as a violation of a constitutional right. BEFA's counsel, by contrast, argued that government had a 'wide discretion' to determine what kind of education package it would deliver but that, once the package had been decided, the state had a constitutional duty to deliver this package. F Rabkin (note 36 above).

${ }^{69}$ An example of this, which the BEFA judgment refers to, is the DBE's Action Plan to 2014 - Towards the Realization of Schooling in $2025^{\prime}$. BEFA (note 1 above) para 42.

${ }^{70} \mathrm{lbid}$.

${ }^{71}$ According to McConnachie \& McConnachie, a determination of the substantive content of the right can involve 'identifying, in broad and general terms, the purposes of basic education, basic learning needs, and the types of inputs required to fulfil these needs'. C McConnachie \& C McConnachie (note 58 above) 580-581.

72 Textbooks 3 (note 5 above) para 46.

${ }^{73}$ The protracted battle between the government and the organisation, Equal Education for the finalisation of the Regulations for School infrastructure is a clear example of this. Government for years resisted publishing binding regulations and instead published guidelines for provinces in the development of school infrastructure development plans. It was only after Equal Education initiated a court application to compel binding regulations did government promulgate such regulations. See for example: F Veriava 'Rich school, poor school - The great divide persists' Mail \& Guardian (September 2012); V John 'Equal Education's struggle with Motshekga - What we know so far' Mail \& Guardian (June 2013).
} 
for ensuring that the basket of educational resources necessary for a learner to receive a basic education are identified and adequately provided for. ${ }^{74}$

This was alluded to in Textbooks $1:^{75}$

In the context of this application one of those components is the provision of text books and while it may be said that no consensus exists broadly in the South African context, on the content of the right to basic education, even though there have been compelling arguments that it must and should, in order to be meaningful, include such issues as infrastructure, learner transport, security at schools, nutrition and such related matters. However, for the purposes of this application it is not necessary to determine those broader issues, or indeed to express the view on that matter, except to say that the arguments that the right must be broad and encompassing, appear to be compelling.

Similarly, in Madzodzo the court held: ${ }^{76}$

The state's obligation to provide basic education as guaranteed by the Constitution is not confined to making places available at schools. It necessarily requires the provision of a range of educational resources: schools, classrooms, teachers, teaching materials and appropriate facilities for learners. It is clear from the evidence presented by the applicants that inadequate resources in the form of insufficient or inappropriate desks and chairs in the classrooms in public schools across the province profoundly undermines the right to basic education.

Finally, in the Tripartite Steering Committee case, Plaskett J, specifically noting the correctness of the Kollapen J statement quoted above states: ${ }^{77}$

The right to education is meaningless without teachers to teach, administrators to keep schools running, desks and other furniture to allow scholars to do their work, text books from which to learn and transport to and from school at State expense in appropriate cases.

Put differently, in instances where scholars' access to schools is hindered by distance and an inability to afford the costs of transport, the State is obliged to provide transport to them in order to meet its obligations, in terms of $s$ 7(2) of the Constitution, to promote and fulfil the right to basic education.

\footnotetext{
${ }^{74}$ The picture that is painted by education researchers analysing learner performance in South Africa across these various cross-national and national studies is bleak. The majority of South Africa learners pass through the education system with little more than basic skills in literacy and numeracy. Moreover, these learners consistently perform worse than their counterparts in other countries. The research also notes the dual nature of the schooling system wherein those that attend relatively advantaged schools are performing at the appropriate grade level and on par with wellperforming international counterparts, while the vast majority, those attending relatively disadvantaged schools 'cannot read for meaning in any language and are not numerically competent'. See B Fleisch Primary Education in Crisis: Why South African Schoolchildren Underachieve in Reading and Mathematics (2009) 3; G Bloch The Toxic Mix: What's Wrong with South Africa's Schools and How to Fix It (2009); N Spaull (note 9 above); S van der Berg and others Low Quality Education as a Poverty Trap (2011).

${ }^{75}$ Textbooks 1 (note 3 above) para 22.

${ }_{77}^{76}$ Madzodzo (note 42 above) para 20.

77 Tripartite Steering Committee (note 66 above) paras 18-19. It is worth noting that there have been several cases in the Eastern Cape aimed at improving education provisioning. Most of these cases, however, tended to be settled out of court and in the applicants' favour. While these cases do not have jurisprudential value, the success of the applicants is perhaps indicative that these educational resources may be viewed as essential components of a basic education. Some of these cases have sought to address poor infrastructure. See Centre for Child Law and Seven Others $v$ Government of the Eastern Cape Province and Others (commonly referred to at the 'Mud schools case') Eastern Cape High Court, Bhisho Case, Case No 504/10 of 2011. For a discussion of the case see: A Skelton 'Leveraging Funds for School Infrastructure: The South African "Mud Schools" Case Study' Int J Dev (2014) 1 and C McConnachie \& C McConnachie (note 58 above). See too Equal Education \& Others v Minister of Basic Education \& Others Eastern Cape High Court, Bhisho Case, Case No 81/2012. Others cases have sought to address personnel provisioning. This has been discussed in brief previously.
} 


\section{(b) A contextualised analysis of the right to equality}

The BEFA judgment explicitly acknowledges the indivisibility and interdependence of socio-economic and civil political rights. ${ }^{78}$ It then undertakes a contexualised analysis to determine whether there has been a violation of the right to equality in terms of $s 9$ of the Constitution. In doing this, it again reaffirms the transformative potential of the Constitution. As Cathi Albertyn notes: ${ }^{79}$

Substantive equality is understood as a remedy to systemic and entrenched inequalities. This requires that judges and lawyers understand the context in which inequality occurs, and identify the social and economic conditions that structure action and create unequal and exclusionary consequences for groups and individuals.

Albertyn then goes on to say that, closely related to the context, is the impact of the impugned action on the individual or group'. ${ }^{80}$ Such a contextual analysis of the impact of the impugned action is crucial to addressing structural inequality. With regard to basic education, it is also significant, given that, increasingly, technological advances, such as the use of tablet devices, have the potential to displace textbooks in the more-resourced schools, while, textbooks at present remain an indispensable tool to teaching and learning in poor and under resourced schools. ${ }^{81}$

Thus, early on, the BEFA judgment notes that the learners affected by the nondelivery of textbooks, are from poor communities, attending 'no-fee' schools, which are the poorest schools, 'and are mostly, if not exclusively', black learners, living in rural areas. $^{82}$ The judgment then makes a point of noting the problems attendant on learning without textbooks under these circumstances. ${ }^{83}$ Applying the tests in South Africa's equality jurisprudence in determining whether there has been unfair discrimination, the SCA notes that the failure to deliver textbooks to even the smallest number of learners - on the government's version, this was about 3 per cent of learners in the Limpopo Province - constituted a violation of those learners' rights to equality and dignity.

In coming to this conclusion, the judgment highlighted the impact of the non-delivery on the 3 per cent of the learners: ${ }^{84}$

Clearly, learners who do not have textbooks are adversely affected. Why should they suffer the indignity of having to borrow from neighbouring schools or copy from a blackboard which cannot, in any event, be used to write the totality of the content of the relevant part of the textbook? Why should poverty stricken schools and learners have to be put to the expense of having to photocopy from the books of other schools? Why should some learners be able to work from textbooks at home and others not? There can be no doubt that those without textbooks are being unlawfully discriminated against.

\footnotetext{
${ }^{78}$ BEFA (note 1 above) para 45.

${ }^{79}$ C Albertyn 'Substantive Equality and Transformation in South Africa' (2007) 23 SAJHR 253, 259.

${ }^{80} \mathrm{lbid}$.

${ }^{81} \mathrm{~K}$ Magubane 'Gauteng gets "paperless" classrooms' Business Day <http://www.bdlive.co.za/national/education/2015/ 01/13/gauteng-gets-paperless-classrooms > and compare with N Stein 'Classrooms of the future?' Ground Up <http:// www.groundup.org.za/article/classrooms-future_2606/>.

82 BEFA (note 1 above).

${ }^{83}$ For example, where learners do not have textbooks, they cannot complete their homework or prepare for lessons or study. Ibid para 19.

84 Ibid para 49.
} 
Accordingly, such a contextualised analysis of the absence of textbooks in impoverished schools and communities illustrates the detrimental impact on learners from these schools and communities to be able to learn and progress.

\section{(c) The duty to budget}

As has been noted above, one of the main arguments of the DBE in the High Court for the failure to deliver textbooks to schools in Limpopo was that it was precluded from procuring 'top-up' textbooks to address shortages because of budgetary constraints, it would, therefore, have to wait for the 2014/2015 budget cycle to acquire textbooks. The DBE further invoked a separation of powers argument suggesting that a failure by the Court to ignore a budgetary constraints argument was tantamount to it interfering in the functions of the other tiers of the government. ${ }^{85}$

The SCA did not hesitate to reject and make rubbish of this argument. ${ }^{86}$ It strongly condemned the DBE's management plan for textbook delivery in its planning, budgeting and implementation of the plan. It noted: ${ }^{87}$

The DBE also had a three-year implementation period during which it could have conducted proper budgetary planning, perfected its database, and ensured accuracy in procurement and efficiency in delivery.

The SCA therefore held: ${ }^{88}$

The DBE's reliance on budgetary constraints and its complaint that the order granted by the court below violated the doctrine of the separation of powers is fallacious and appears contrived.

While the SCA did not explicitly refer to other judgments, the underlying rationale for the SCA's rejection of a budgetary constraints argument appears to be similar to that adopted in other socio-economic rights cases where the courts have held that there is an implicit duty on government to budget effectively. In the case of City of Johannesburg Metropolitan Municipality v Blue Moonlight Properties 39 Pty (Ltd) and Another, the Constitutional Court held: ${ }^{89}$

This Court's determination of the reasonableness of measures within available resources cannot be restricted by budgetary and other decisions that may well have resulted from a mistaken understanding of constitutional or statutory obligations. In other words, it is not good enough for the City to state that it has not budgeted for something, if it should indeed have planned and budgeted for it in the fulfilment of its obligations. (Own emphasis.)

Similarly, in Madzodzo, Goosen J dismissed the argument that there were insufficient funds budgeted to meet all the furniture needs immediately. Rather than allowing

\footnotetext{
${ }^{85}$ BEFA (note 1 above) para 29.

${ }^{86}$ At the hearing Cachalia J refuted arguments of budgetary constraints on the basis that this was tantamount to a 'bald allegation' and that government had failed to provide any argument of this. F Rabkin (note 36 above). While Navsa J stated at the hearing that 'separation of powers is the new equivalent of the floodgates argument' thus suggesting that the separation of powers argument is invoked indiscriminately by parties in the courts these days. Author's notes from the hearing.

${ }^{87}$ BEFA (note 1 above) para 43.

${ }^{88} \mathrm{Ibid}$.

${ }^{89} 2012$ (2) SA 104 (CC) para 74.
} 
government to rely on this argument as a justification for not complying with previous court orders, Goosen J found that government had failed to budget proactively for furniture shortages even though it ought to have based its budget on relevant information that was available at the time the budget was decided. ${ }^{90}$

Thus, the decision in the BEFA judgment to preclude government from relying on a budgetary constraints argument in circumstances where it had failed to budget for textbooks in accordance with its management plan for the roll out of CAPS textbooks is significant. This is because the holding confirms and strengthens the developing principle in socio-economic rights cases that government is required to budget effectively so as to meet its socio-economic rights obligations.

\section{(d) The remedy}

The SCA dismissed the DBE appeal with costs and granted BEFA's cross appeal relating to the non-compliance with previous court orders. As noted earlier, BEFA did not pursue the structural relief in its cross-appeal. The SCA, in determining the appropriate relief, noted that the relief granted by the High Court had been over taken by time and that it was necessary to 're craft' the order to ensure that the DBE met its obligations for future textbook delivery. It then granted a comprehensive declaratory order. ${ }^{91}$ It declared that there had been non-compliance with the various court orders of Kollapen J. It declared that the right to basic education included the right of every learner 'to be provided with every textbook prescribed for his or her grade before commencement of the teaching of the course for which the textbook is prescribed' and that the corollary of this was the obligation of the DBE to provide such textbooks. Finally, the SCA declared that the failure to provide the textbooks violated the rights to basic education, equality and dignity of learners in Limpopo.

The rationale of BEFA's counsel in not pursuing the structural relief was that such relief potentially risked providing the DBE with yet another opportunity to return to court to continue to attempt to justify its reasons for continued non-delivery. This has in fact been the experience of some of the other education provisioning cases in which structural relief was granted. ${ }^{92}$ BEFA's counsel, therefore, opted to argue for a final declarator that would enable BEFA (or any other party) to return to court for ongoing or future non-delivery of textbooks. BEFA, together with Section 27, have instead turned its attention to developing a multipronged monitoring plan to ensure textbook delivery. ${ }^{93}$

\footnotetext{
90 Madzodzo (note 42 above) para 35.

${ }^{91}$ At the hearing, the parties were asked if they would be willing to provide a draft court order in the event of SCA finding against the DBE.

${ }_{92}$ For example, in the Madzodzo case, the Minister was directed to deliver all furniture to schools in the province by 30 May 2014. The court also gave the Minister an opportunity to approach the court for an extension of the time frame. The Minister later applied to court for an extension of the deadline. This led to a fourth court order detailing new time frames, new obligations and new reporting requirements.

${ }^{93}$ This multi-pronged monitoring plan has included the publicising of the judgment in the Limpopo Province through the media and through workshops. This is to encourage parents and learners to report shortages. BEFA has also obtained formal permission from the LDoE to access public schools to monitor textbook delivery. Section 27 has also been liaising with the SAHRC regarding the development of a monitoring plan to ensure the reporting of textbook shortages nationally to parliament and to the DBE.
} 
The monitoring of court orders by organisations to ensure implementation is acknowledged as an effective strategy for successful public interest litigation. ${ }^{94}$ At the same time, it must be noted that such a choice of strategy for ensuring the implementation of a court order should not detract from the value of structural relief as a remedy, particularly in the context of socio-economic rights adjudication. ${ }^{95}$

However, in the circumstances of this case and particularly within the context of the non-compliance with the first three court orders, an alternative strategy was adopted to ensure the implementation of the SCA judgment. Such a multi-pronged monitoring strategy would obviously not be viable without an organisation like BEFA, together with Section 27, to pursue it.

Indeed, within the context of government failing to abide by court orders in several education provisioning cases, civil society organisations are increasingly experimenting with different remedies to ensure government compliance with court orders. $^{96}$ Ultimately, the purpose of textbook litigation has been, in the face of government recalcitrance, to improve governance and accountability in textbook delivery and ensure that government fulfils its rights obligations to the learners of Limpopo.

\section{Conclusion}

The analysis of the BEFA judgment in this article suggests that the case may be viewed as a partial triumph of transformative constitutionalism. It does this through the confirmation and adoption of the 'transformative narrative' that confirms the 'immediate realisation' principle and through its substantive approach to interpreting the right to basic education. In doing this, the judgment potentially opens new frontiers for the normative development of the right to basic education. The transformative potential of the Constitution is further realised through the contextualised analysis of the necessity of textbooks in under resourced schools. The judgment entrenches the principle of the duty to budget in the evolving socio-economic rights jurisprudence of our courts. As such, this precludes government from making 'bald assertions' of budgetary constraints, but instead requires government to engage in rational planning and allocations in respect of education provisioning.

While the judgment is to be hailed for its transformative potential, the article warns that failure to adopt an objective test for determining whether there has been a violation of the right to basic education in education provisioning cases, in deference to government policy processes, could detrimentally impact on future education

\footnotetext{
${ }^{94} \mathrm{G}$ Marcus \& S Budlender 'An evaluation of strategic public interest litigation in South Africa' (2008) Atlantic Philanthropies Report. See too S Budlender, G Marcus SC \& N Ferrira Public Interest Litigation and Social Change in South Africa: Strategies, Tactics and Lessons (2014); M Heywood 'Preventing Mother-to-Child HIV Transmission in South Africa: Background, Strategies and Outcomes of the Treatment Action Case against the Minister of Health' (2003) 19 SAJHR 278.

${ }_{95}$ Roach and Budlender, for example, set out the circumstances in which structural orders can serve as effective remedies. K Roach \& G Budlender "Mandatory Relief and Supervisory Jurisdiction: When Is It Appropriate, Just and Equitable" SALJ 122 (2005) 333.

${ }_{96}$ Another example of this is the string of post-provisioning cases referred to above. During the first round of cases and after several court orders and the failure of the Eastern Cape provincial department of education to meet the deadline for the payment of the remuneration of teachers, steps were taken to attach state assets to be sold if the debt was not satisfied within the requisite time. In the Linkside litigation, an administrator was appointed in a class action litigation to oversee the payments of salaries to educators. See the Legal Resources Centre publications (note 67 above).
} 
provisioning cases. It is submitted that, in the context of a seemingly never-ending education crisis in South Africa, there are compelling reasons for determining the basket of entitlements for the fulfilment of the right to basic education.

Finally, the article discusses the background and rationale to the declarator in the judgment. It further notes the developing trend within civil society - especially in education provisioning cases - for seeking creative approaches in the formulation of remedies in the face of having to return to court repeatedly because of non-compliance with previous court orders.

\section{Notes on contributor}

Faranaaz Veriava, Lawyer and Senior Legal Researcher at Section 27, LLD Candidate at the University of Pretoria.

\section{Acknowledgements}

I am grateful for the comments and guidance of my supervisor, Prof. Ann Skelton as well as that of Dr Kenneth Creamer and the two anonymous reviewers.

\section{Disclosure statement}

The authors report no conflicts of interest. The authors alone are responsible for the content and writing of this article. 